\title{
ResearchArticle
}

\section{Studies on seed quality characters in green gram cv. KM2}

\author{
A. Kamaraj and S. Padmavathi
}

\section{SUMMARY}

Green gram is one of the major pulse crops, mainly cultivated as a rainfed crop under rice fallow condition. The low productivity under rainfed condition is due to soil moisture deficit, uneven rainfall, low soil fertility and poor crop management. To overcome this problem, seed hardening techniques is recommended to alleviate the moisture stress condition. The present study was emphasized on the effect of seed hardening using various leaf extract like Prosopis, Pungam, Nochi, Neem,Umathai, Aduthoda, Nerium, papaya, bittergourd etc. on seed and seedling characteristics like germination per cent, speed of germination, accumulated speed of germination, mean daily germination, root length, shoot length, seedling length, dry matter production, seedling vigour-I and seedling vigour-II of green gram KM 2 . The results revealed that green gram seeds hardened with 1 per cent Prosopis leaf extract for 3 hours @ 1/3 rd volume of solution enhanced the seed and seedling quality characteristics. under adverse environment conditions.

Key Words : Greengram, Leaf extract, Seed hardening, Seed quality, Prosopis, Pungam

How to cite this article : Kamaraj, A. and Padmavathi, S. (2018). Studies on seed quality characters in green gram cv. KM2. Internat. J. Plant Sci., 13 (2): 223-228, DOI: 10.15740/HAS/IJPS/13.2/223-228, Copyright@ 2018: Hind Agri-Horticultural Society.

Article chronicle : Received : 01.12.2017; Revised : 04.06.2018; Accepted : 17.06.2018

\section{MEMBERS OF THE RESEARCH FORUM}

Author to be contacted :

A. Kamaraj, Department of Genetics and Plant Breeding, Faculty of Agriculture, Annamalai University, Chidambaram (T.N.) India

Email : a.kamaraj@yahoo.co.in

Address of the Co-authors:

S. Padmavathi, Department of Genetics and Plant Breeding, Faculty of Agriculture, Annamalai University, Chidambaram (T.N.) India 